\title{
Prevention and early diagnosis of oral cancer - a literature review
}

\author{
Manoela Garcia Dias ${ }^{a}$, Ana Cláudia Figueirób ${ }^{b}$ Vera Lucia Luiza ${ }^{c}$
}

\begin{abstract}
INTRODUCTION: The present study identified and described scientific production on primary and secondary prevention of oral cancer worldwide. This is an integrative review of the literature, focusing on the description of oral cancer prevention experiences.

METHODS: The search was performed in the Virtual Health Library (VHL), using the descriptors: early diagnosis, oral neoplasms, primary prevention and secondary prevention. We found 225 articles and selected 22 after evaluation, divided into three themes.

RESULTS: Four articles awareness-raising and population-tracking campaigns with the valorization of the role of the dental surgeon and the involvement of health teams. The non-invasive diagnostic methods, considered in fifteen articles, addressed the implementation of new strategies for the early detection of this pathology by different diagnostic methods. The reorganization of the health system ( 3 articles) encompassed the permanent education of oral health professionals, epidemiological surveillance and reorganization of health services with integration of health care levels. The great majority of the reviewed experiences showed positive results in the prevention of oral cancer. An exception was the active search for suspected cases in the population, since the cost benefit did not compensate the expenditure with human resources for this purpose. The non-invasive methods reported are useful for screening but do not substitute the biopsia for diagnosis.
\end{abstract}

Keywords: oral cancer; primary prevention; secondary prevention; early diagnosis.

\section{Prevenção e diagnóstico precoce do câncer oral - uma revisão da literatura}

\section{RESUMO}

INTRODUÇÃO: O estudo identificou e descreveu a produção científica sobre prevenção primária e secundária do câncer oral no mundo. Foi uma revisão integrativa da literatura, com foco na descrição de experiências de prevenção do câncer oral.

METODOLOGIA: A busca foi realizada na Biblioteca Virtual de Saúde (BVS), utilizando os descritores: diagnóstico precoce, neoplasias bucais, prevenção primária e prevenção secundária. Foram encontrados 225 artigos, selecionados 22 após a avaliação, divididos em três temáticas.

RESULTADOS: Quatro artigos abordaram as campanhas de conscientização e rastreamento populacional com a valorização do papel do cirurgião-dentista e do envolvimento das equipes de saúde. Os métodos de diagnóstico não-invasivo, contemplados em quinze artigos, abordaram a implementação de novas estratégias de detecção precoce dessa patologia por diferentes métodos diagnósticos. A reorganização do sistema de saúde (3 artigos) considerou a educação permanente dos profissionais, vigilância epidemiológica e reorganização dos serviços de saúde com integração dos níveis de atenção à saúde. A grande maioria das experiências revisadas mostrou resultados positivos na prevenção do câncer oral. Foi exceção a busca ativa por casos suspeitos na população, pois o custo benefício não compensou o gasto com recursos humanos. Os métodos não invasivos relatados se mostram úteis para rastreio, mas não substituem a biopsia para diagnóstico.

Palavras-chave: câncer oral; prevenção primária; prevenção secundária; diagnóstico precoce.
${ }^{a}$ Nurse. PhD student in Public Health. Escola Nacional Saúde Pública Sérgio Arouca, ENSP, Fundação Oswaldo Cruz, FIOCRUZ, Rio de Janeiro, RJ, Brasil

${ }^{b}$ Nutritionist. PhD in Public Health. Assistant researcher. Endemic Department Samuel Pessoa Escola Nacional de Saúde Pública Sergio Arouca, ENSP, Fundação Oswaldo Cruz, FIOCRUZ, Rio de Janeiro, RJ, Brasil

${ }^{c}$ Pharmacist. PhD in Public Health. Researcher Department of Drug Policy and Pharmaceutical Care, Escola Nacional de Saúde Pública Sergio Arouca, ENSP, Fundação Oswaldo Cruz, FIOCRUZ, Rio de Janeiro, RJ, Brasil

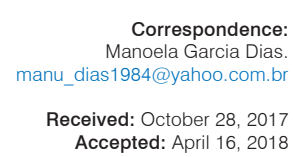

Accepted: April 16, 2018

Conflict of Interests: The authors state that there re no financial and personal conflicts of interest that could have inappropriately influenced their work.

Copyright: (c) 2017 Dias et al.; licensee EDIPUCRS.

This work is licensed under a Creative Commons Attribution 4.0 International License. 


\section{INTRODUCTION}

Oral health $(\mathrm{OH})$ is part of general health and implies being free of chronic orofacial pain, oral and pharyngeal cancer, changes in soft tissues of the mouth, congenital malformations or other disorders affecting the craniofacial complex [1]. In addition to dental conditions causing pain and infections, leading to psychic suffering, they also lead to social exclusion, since they are associated with poor schooling, low income, unemployment and difficulty in accessing care services [2].

Oral cancer is one of the oral affections and affects, for the most part, people with low sociocultural level, alcoholics and smokers [3]. It is a worldwide public health problem due to its high morbidity and mortality rate and for reaching, mostly, the population of working age. This causes direct damages to individuals and families, negatively affecting their quality of life, as well as indirect damages to the country [3].

It was estimated in 2013 that $1.8 \%$ of people aged 18 years or more (2.7 million adults) had reported a medical diagnosis of cancer in Brazil. The proportion in the urban area was higher than in the rural area, respectively, $1.9 \%$ and $1.2 \%$ [4]. According to the National Cancer Institute (INCA), for 2016 and 2017 it was estimated the occurrence of approximately 596,000 new cases of cancer in each of the years, reinforcing the magnitude of the cancer problem in the country. Oral cancer is the fifth most prevalent among the male population and the sixth in the female population, although with regional variation. The incidence of oral cancer was estimated in 11,140 new cases (estimated risk of 11.27 cases per 100,000 ) in the male population and around 4,350 (estimated risk of 4.21 cases per 100,000) in the female population for the year 2016 [4].

Dysphagia, hoarseness, odynophagia and lesions in the oral cavity that do not heal for more than two weeks are some symptoms, and the occurrence of any of these should rouse the search of a professional to make the diagnosis as early as possible. These symptoms can be identified in routine examinations, which should be done periodically. The active search of individuals who have complaints in the oral cavity should generate priority health care in these cases and follow up [6].

This type of cancer has $80 \%$ to $90 \%$ chances of cure when diagnosed and treated in the initial phase (stages I and II). If not diagnosed early, it can cause incapacitating sequel and the need for a more complex and mutilating treatment, resulting in greater financial and social loss [7].

Brazil counts on a program for the early diagnosis, which recommends, among other actions, the prevention and control of oral cancer [6]. However, $65-85 \%$ of the cases are diagnosed late [7]. Thus, identifying methods of diagnosis of oral cancer and measures to prevent this pathology in different health systems in the world and in the country is relevant, pointing to the facilities and difficulties of implementing methods and preventive measures.

In this sense, this article aims to identify and describe the scientific production on experiences of primary and secondary prevention of oral cancer and the results obtained, focusing on primary and secondary health care.

\section{METHODS}

This is an integrative review of the literature [8], whose inclusion criteria were publications in peer-reviewed journals or theses/dissertations published in Portuguese, English or Spanish between 2004 and 2015. The choice of publication period was based on the year of publication of the National Oral Health Policy in Brazil [9].

We considered studies with primary data collection or use of secondary bases, regardless of approach, either qualitative or quantitative. Studies that addressed actions of primary and secondary prevention of actions directed at oral cancer aimed at users, professionals or services, both with direct and educational interventions were included. We also considered the models of reorganization of health services with a focus on $\mathrm{OH}$ that aimed to improve the reference system and counter-reference to favor early diagnosis and treatment in a timely manner.

Laboratory-based studies, those restricted to tertiary care, single case studies and those assessing the conduct and knowledge of the professionals involved, or academic education, were excluded.

In the search conducted between August and September 2015 and updated in May 2017, using the Virtual Health Library (VHL), articles were consulted in the databases LILACS, SciELO, MEDLINE and BDENF, combining the terms "early diagnosis" and "oral neoplasias", with "primary prevention" and "secondary prevention", with the corresponding translations in English and Spanish. The search resulted in the inclusion of 22 articles. The flowchart is presented in Figure 1. The procedures for selecting and extracting data were conducted by the first author and reviewed by the others.

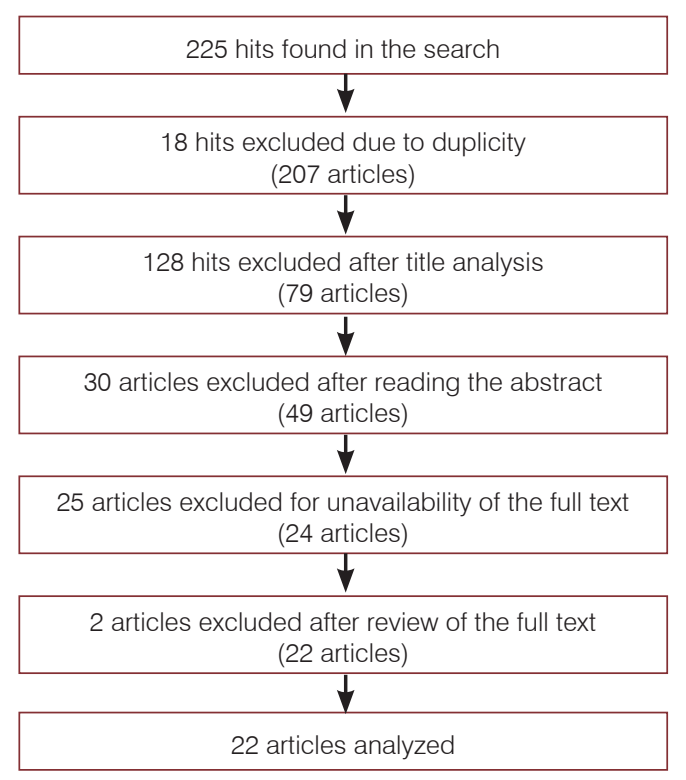

Figure 1. Flowchart of search for articles. 
The articles were tabulated in a spreadsheet in MS Excel $^{\circledR}$ version 2010 including the following information: title, authors, year of publication, language of the text, place and year of data, type of publication (article or thesis/ dissertation), the main focus of the study (awareness-raising and population-tracking campaigns, methods of noninvasive diagnosis, and reorganization of the health system), intervention, study objective, design, study population (users, professionals, organizations).

For the analysis, the papers were grouped according to the central theme, considering those related to the activities performed in the primary and secondary health care, identifying the characteristics and highlighting the relevant conclusions. This process was reviewed by all the authors.

\section{RESULTS}

As for the characteristics of the 22 studies included in the sample, the majority (11 studies) were carried out in Brazil. We also found publications of studies conducted in the United States, India and Thailand and a higher concentration of publications in 2015 (6 studies). Twenty publications were articles and two were doctoral theses. As for the population of the studies, 18 studies addressed patients, two approached health professionals, and two approached the health institution.

As for the design, 19 studies were of quantitative approach, and three of quantitative-qualitative approach. As for the language of publication, eight were in Portuguese, and fourteen in English language.

Regarding the thematic classification, most of the articles (15 studies) addressed non-invasive diagnostic methods, four of them addressed awareness-raising and populationtracking campaigns, and three addressed the reorganization of the health system (Table 1).

\section{Awareness-raising and population-tracking campaigns}

Studies classified in this category [10-13] focused on prevention and early diagnosis activities carried out systematically in the areas covered by primary health care services. These activities were generally carried out in combination with other campaigns that had already been well structured, such as the vaccination campaign for the elderly population [10]. In the case of this specific example, this proved to be a good strategy for raising the population awareness, especially in the age group with the highest incidence of oral cancer. It also facilitated contact with a population that considered visiting the dentist unnecessary due to edentulism.

Table 1. Characterization of articles included in the study.

\begin{tabular}{|c|c|c|c|c|c|}
\hline Título & $\begin{array}{l}\text { Período dos } \\
\text { dados }\end{array}$ & $\begin{array}{l}\text { Local de realização } \\
\text { do estudo }\end{array}$ & Intervention & Objective & Main conclusions \\
\hline \multicolumn{6}{|l|}{$\begin{array}{l}\text { AWARENESS-RAISING AND } \\
\text { POPULATION-TRACKING } \\
\text { CAMPAIGNS }\end{array}$} \\
\hline $\begin{array}{l}\text { Early Detection of potentially } \\
\text { malignant oral lesions in two } \\
\text { cities of Pernambuco [12]. }\end{array}$ & Uninformed & Brazil (Pernambuco) & $\begin{array}{l}\text { The } 448 \text { participants of } \\
\text { explanatory lecture held in } \\
\text { public places were submitted } \\
\text { to clinical examination of the } \\
\text { oral cavity and suspected } \\
\text { cases were referred to } \\
\text { specialized dental care. }\end{array}$ & $\begin{array}{l}\text { To evaluate the presence of } \\
\text { potentially malignant oral } \\
\text { lesions in residents of two } \\
\text { municipalities in the regions } \\
\text { Zona da Mata and Sertão of } \\
\text { the State of Pernambuco. }\end{array}$ & $\begin{array}{l}\text { Twenty six potentially malignant } \\
\text { oral lesions were identified } \\
\text { in } 448 \text { residents in a state } \\
\text { that counts on few programs } \\
\text { targeting the early detection of } \\
\text { oral cancer. }\end{array}$ \\
\hline $\begin{array}{l}\text { Strategies and results of } \\
\text { the oral cancer prevention } \\
\text { campaign among the elderly } \\
\text { in São Paulo, Brazil, } 2001 \text { to } \\
\text { 2009.[13]. }\end{array}$ & 2001-2009 & Brazil (São Paulo) & $\begin{array}{l}\text { Training of professionals, } \\
\text { development of printed } \\
\text { material with guidelines } \\
\text { to conduct campaigns for } \\
\text { prevention, tracking, and } \\
\text { referral of suspected cases } \\
\text { were performed. }\end{array}$ & $\begin{array}{l}\text { To describe strategies and } \\
\text { results of campaign aimed } \\
\text { at early diagnosis and } \\
\text { prevention of oral cancer for } \\
\text { the population aged } 60 \text { and } \\
\text { over developed since } 2001 \text { in } \\
\text { the State of São Paulo. }\end{array}$ & $\begin{array}{l}\text { There was implementation } \\
\text { of both educational and } \\
\text { management strategies of } \\
\text { different natures. A significant } \\
\text { reduction in the rate of } \\
\text { confirmed cases of oral cancer } \\
\text { was reached between } 2005 \text { and } \\
2009 \text {, allowing concluding that } \\
\text { there were benefits to the oral } \\
\text { health of the elderly population. }\end{array}$ \\
\hline $\begin{array}{l}\text { The effectiveness of the oral } \\
\text { cancer prevention and early } \\
\text { diagnosis program in São } \\
\text { Paulo, Brazil [10]. }\end{array}$ & 2004 & Brazil (São Paulo) & $\begin{array}{l}\text { A campaign for prevention and } \\
\text { early diagnosis of oral cancer } \\
\text { was carried out together with } \\
\text { elderly vaccination campaign. }\end{array}$ & $\begin{array}{l}\text { To evaluate the results of the } \\
\text { campaign for prevention and } \\
\text { early diagnosis of oral cancer } \\
\text { carried out in the together } \\
\text { with the elderly vaccination } \\
\text { campaign against in the State } \\
\text { of São Paulo in } 2004 \text {. }\end{array}$ & $\begin{array}{l}\text { The campaign showed to be } \\
\text { ineffective in view of the high } \\
\text { proportion of patients whose } \\
\text { soft tissue lesions could not } \\
\text { be solved, besides the lack } \\
\text { of monitoring of prevention } \\
\text { campaign results in most of } \\
\text { the state. }\end{array}$ \\
\hline $\begin{array}{l}\text { Preventing and detecting oral } \\
\text { cancer: Oral health } \\
\text { care providers' readiness } \\
\text { to provide health behavior } \\
\text { counseling and oral cancer } \\
\text { examinations [11]. }\end{array}$ & 2002 & $\begin{array}{l}\text { United States } \\
\text { (New York State) }\end{array}$ & $\begin{array}{l}\text { Research on the practice of } \\
\text { dentists in the prevention and } \\
\text { tracking of oral cancer. }\end{array}$ & $\begin{array}{l}\text { To assess the practice } \\
\text { standards for prevention and } \\
\text { early detection of oral cancer. }\end{array}$ & $\begin{array}{l}\text { The oral cancer examination } \\
\text { seemed to be adopted as a } \\
\text { standard practice by most } \\
\text { state providers, but prevention } \\
\text { services, such as counseling } \\
\text { to stop smoking and alcohol } \\
\text { abuse, were insufficient. }\end{array}$ \\
\hline
\end{tabular}


Table 1 (continuation)

\begin{tabular}{|c|c|c|c|c|c|}
\hline Título & $\begin{array}{l}\text { Período dos } \\
\text { dados }\end{array}$ & $\begin{array}{l}\text { Local de realização } \\
\text { do estudo }\end{array}$ & Intervention & Objective & Main conclusions \\
\hline \multicolumn{6}{|l|}{$\begin{array}{l}\text { NON-INVASIVE DIAGNOSTIC } \\
\text { METHODS }\end{array}$} \\
\hline $\begin{array}{l}\text { Silicon Nanowire biosensor } \\
\text { for highly sensitive and } \\
\text { multiplexed detection of oral } \\
\text { squamous cell carcinoma } \\
\text { biomarkers in saliva [28]. }\end{array}$ & Uninformed & China & $\begin{array}{l}\text { Application of the silicone } \\
\text { nanowire biosensor for the } \\
\text { detection of biomarkers related } \\
\text { to the presence of the tumor. }\end{array}$ & $\begin{array}{l}\text { To evaluate the specificity and } \\
\text { sensitivity of this method. }\end{array}$ & $\begin{array}{l}\text { This method was capable to } \\
\text { detect these factors in saliva, } \\
\text { besides being low cost. It was } \\
\text { considered a valid tool for the } \\
\text { diagnosis. }\end{array}$ \\
\hline $\begin{array}{l}\text { Serum big endothelin-1 as a } \\
\text { biomarker in oral squamous } \\
\text { cell carcionoma patients: an } \\
\text { analytical study [27]. }\end{array}$ & Uninformed & India (Aurangabad) & $\begin{array}{l}\text { Evaluation of the level of } \\
\text { endothelin- } 1 \text { in people with } \\
\text { oral cancer. }\end{array}$ & $\begin{array}{l}\text { To evaluate the use of } \\
\text { endothelin-1 as a blood } \\
\text { biomarker to correlate clinical } \\
\text { staging and histological } \\
\text { classification. }\end{array}$ & $\begin{array}{l}\text { This marker can facilitate early } \\
\text { detection through blood test. It } \\
\text { is also a method for population } \\
\text { screening. }\end{array}$ \\
\hline $\begin{array}{l}\text { Diagnostic model of saliva } \\
\text { peptide finger print analysis } \\
\text { of oral squamous cell } \\
\text { carcinoma patients using } \\
\text { weak cation exchange } \\
\text { magnetic beads [26]. }\end{array}$ & 2013-2014 & China & $\begin{array}{l}\text { Use of the MALDI-TOF MS } \\
\text { method to identify biomarkers. }\end{array}$ & $\begin{array}{l}\text { To identify specific biomarkers } \\
\text { in saliva. }\end{array}$ & $\begin{array}{l}\text { The identification of biomarkers } \\
\text { may facilitate the diagnosis, but } \\
\text { multicenter studies are needed } \\
\text { to validate the method. }\end{array}$ \\
\hline $\begin{array}{l}\text { Molecular genetic study of } \\
\text { novel biomarkers for the early } \\
\text { diagnosis of oral squamous } \\
\text { cell carcinoma [25]. }\end{array}$ & $2011-2012$ & Korea (Seoul) & $\begin{array}{l}\text { Microanalysis of tumor tissue } \\
\text { to identify genes associated } \\
\text { with change. }\end{array}$ & $\begin{array}{l}\text { To identify the expression of } \\
\text { genes associated with the } \\
\text { presence of oral cancer. }\end{array}$ & $\begin{array}{l}\text { It was found that the presence } \\
\text { of four genes in combination is } \\
\text { candidate as a biomarker for } \\
\text { this type of câncer. }\end{array}$ \\
\hline $\begin{array}{l}\text { Gene expression profiling } \\
\text { signatures for the diagnosis } \\
\text { and prevention of oral cavity } \\
\text { carcinogenesis-genome- } \\
\text { wide analysis using RNA-seq } \\
\text { technology [24]. }\end{array}$ & Uninformed & $\begin{array}{l}\text { United States } \\
\text { (New York) }\end{array}$ & $\begin{array}{l}\text { Use of } 4-N Q O \text { to identify } \\
\text { genetic expression. }\end{array}$ & $\begin{array}{l}\text { To compare the genetic } \\
\text { expression in the early and } \\
\text { advanced stages of oral } \\
\text { cancer. }\end{array}$ & $\begin{array}{l}\text { The identification of biomarkers } \\
\text { can facilitate the diagnosis in } \\
\text { people with risk factors, and } \\
\text { distinguish the stage of the } \\
\text { disease. }\end{array}$ \\
\hline $\begin{array}{l}\text { Clinical correlative study } \\
\text { on early detection of oral } \\
\text { cancer and precancerous } \\
\text { lesions by modified oral } \\
\text { brush biopsy and cytology } \\
\text { followed by histopathology por } \\
\text { histopatologia [23]. }\end{array}$ & Uninformed & Índia (Gujarat). & $\begin{array}{l}\text { Application of the modified } \\
\text { brush biopsy and exfoliative } \\
\text { cytology method was } \\
\text { performed on } 225 \text { oral } \\
\text { lesions clinically diagnosed } \\
\text { as precancerous, selected } \\
\text { from } 1099 \text { lesions in } 877 \\
\text { patients, while scalpel } \\
\text { or punch biopsies were } \\
\text { performed based on clinical } \\
\text { and cytological evidence in } \\
117 \text { lesions. }\end{array}$ & $\begin{array}{l}\text { To evaluate and compare the } \\
\text { clinical usefulness and the } \\
\text { efficacy of exfoliative cytology, } \\
\text { modified brush biopsy (without } \\
\text { computerized analysis) and } \\
\text { biopsy in the early detection of } \\
\text { premalignant and malignant } \\
\text { oral lesions. }\end{array}$ & $\begin{array}{l}\text { Modified brush biopsy was } \\
\text { more effective than routine } \\
\text { cytology and could be used } \\
\text { as a practical screening tool } \\
\text { for oral cancer, favoring the } \\
\text { early detection of lesions with } \\
\text { malignant potential. }\end{array}$ \\
\hline $\begin{array}{l}\text { Concordance between } \\
\text { cytopathology and incisional } \\
\text { biopsy in the diagnosis } \\
\text { of oral squamous cell } \\
\text { carcinoma [22]. }\end{array}$ & $2002-2010$ & Brazil (Rio de Janeiro) & $\begin{array}{l}\text { The patients (172) underwent } \\
\text { cytological examination } \\
\text { followed by incisional biopsy to } \\
\text { compare these methods. }\end{array}$ & $\begin{array}{l}\text { To evaluate the sensitivity, } \\
\text { specificity, positive and } \\
\text { negative predictive values } \\
\text { and cytopathology precision } \\
\text { for the diagnosis of oral } \\
\text { squamous cells. }\end{array}$ & $\begin{array}{l}\text { The sensitivity of oral } \\
\text { cytopathology was enough to } \\
\text { justify its use as a diagnostic } \\
\text { screening to test and confirm } \\
\text { the malignant nature of } \\
\text { epithelial cells, mainly for the } \\
\text { classification of oral squamous } \\
\text { cells. }\end{array}$ \\
\hline $\begin{array}{l}\text { Diagnostic accuracy of diffuse } \\
\text { reflectance imaging for early } \\
\text { detection of pre-malignant } \\
\text { and malignant changes in } \\
\text { the oral cavity: a feasibility } \\
\text { study [21]. }\end{array}$ & 2010 & India (Trivandrum) & $\begin{array}{l}\text { Development of oral lesion } \\
\text { diagnosis method (by } \\
\text { the multi-spectral diffuse } \\
\text { reflectance imaging system) } \\
\text { applied to } 55 \text { patients and } 23 \\
\text { healthy volunteers. The tissue } \\
\text { biopsy and histopathology } \\
\text { were used as gold standard. }\end{array}$ & $\begin{array}{l}\text { To compare the accuracy } \\
\text { of the multi-spectral diffuse } \\
\text { reflectance imaging system } \\
\text { in relation to the gold } \\
\text { standard of tissue biopsy and } \\
\text { histopathological examination. }\end{array}$ & $\begin{array}{l}\text { The diffuse reflectance was } \\
\text { effective as a screening tool } \\
\text { because it found malignant } \\
\text { areas with good diagnostic } \\
\text { accuracy compared to the gold } \\
\text { standard. }\end{array}$ \\
\hline $\begin{array}{l}\text { The intraoral video camera: } \\
\text { a diagnostic tool in the exam } \\
\text { of patient with increased oral } \\
\text { cancer risk [20]. }\end{array}$ & $\begin{array}{l}\text { Não } \\
\text { informado }\end{array}$ & Brazil (Rio de Janeiro) & $\begin{array}{l}\text { A videoroscopy preceded by } \\
\text { examination without help of } \\
\text { any magnifying device was } \\
\text { performed in patients and } \\
\text { found precursor epithelial } \\
\text { lesions or lichen planus. }\end{array}$ & $\begin{array}{l}\text { To compare the findings of } \\
\text { clinical examination of the oral } \\
\text { cavity with and without the aid } \\
\text { of an intraoral video camera } \\
\text { ("videoroscopy") in order to } \\
\text { diagnose precursor lesions } \\
\text { and precancerous conditions } \\
\text { (lichen planus). }\end{array}$ & $\begin{array}{l}\text { Of the patients with precursor } \\
\text { epithelial lesion or lichen } \\
\text { planus, } 80 \% \text { of lesions were } \\
\text { observed in both exams, while } \\
7 \% \text { were only diagnosed after } \\
\text { videoroscopy. Videoroscopy } \\
\text { was useful for patients at } \\
\text { increased risk for oral cancer in } \\
\text { order to assist in the diagnosis } \\
\text { of early lesions, in the selection } \\
\text { of the best area for biopsy } \\
\text { and in the follow-up of these } \\
\text { lesions }\end{array}$ \\
\hline
\end{tabular}


Table 1 (continuation)

\begin{tabular}{|c|c|c|c|}
\hline Título & $\begin{array}{l}\text { Período dos } \\
\text { dados }\end{array}$ & $\begin{array}{l}\text { Local de realização } \\
\text { do estudo }\end{array}$ & Intervention \\
\hline $\begin{array}{l}\text { Fluorescence spectroscopy } \\
\text { for noninvasive early diagnosis } \\
\text { of oral mucosal malignant } \\
\text { and potentially malignant } \\
\text { lesions [29]. }\end{array}$ & Uninformed & $\begin{array}{l}\text { India (province not } \\
\text { informed) }\end{array}$ & $\begin{array}{l}\text { Use of fluorescence } \\
\text { spectroscopy in } 170 \text { people } \\
\text { ( } 26 \text { healthy volunteers and } 144 \\
\text { patients); histopathology was } \\
\text { the gold standard. }\end{array}$ \\
\hline
\end{tabular}

\section{Objective}

To evaluate the potential of the fluorescence spectroscopy method to differentiate lesions in the oral cavity.

\section{Characterization of different}

tissue changes in normal,

betel chewers, potentially

malignant lesions, conditions

and oral squamous cell

carcinoma using reflectance

confocal microscopy:

correlation with routine

histopathology [18].

\section{Contact endoscopy \\ (microstomatoscopy) in ora \\ lesions: evaluation of the}

method [17]

\section{Uninformed India (Chennai)}

\section{Brazil (São Paulo)}

Application of
microstomatos

microstomatoscopy in 100

patients with lesions, followed

by comparison of these results with the histopathological result.
Biopsy of the lesions and reflectance evaluation were performed in 25 patients with suspected lesions.
The application of acetic acid in the detection of oral squamous cell carcinoma [16].
Uninformed Thailand (Bangkok)

i

The application of acetic acid in 30 patients with suspicious lesions, comparing the result with that of the biopsy.

\begin{abstract}
Evaluation of the cytology and
1988-1989 Brazil (Curitiba) the toluidine blue test in the diagnosis of oral malignant tumors [15].
\end{abstract}

Application of the toluidine blue test in 100 patients seen in the CP sector, comparing with the cytopathological examination of the lesion.
To evaluate the characteristics of the normal mucosa, mucosa of betel smokers, mucosa with potentially malignant lesion and squamous cell carcinoma of the oral mucosa by using focal reflectance microscopy.

To describe the difficulties of microstomatoscopy when applied to the lesions of the mouth and lower lip (including lip vermilion), as well as to verify whether the criteria already used in this same type of examination for other topographies are also amenable to analysis in these places.

To evaluate the sensitivity, specificity and precision of the use of vinegar ( $5 \%$ acetic acid) for the examination of oral cancer. It was a secondary objective to investigate the association between clinical examination using acetic acid and expression of the p53 tumor marker.

To determine the sensitivity and negative predictive value of the exfoliative cytology examination and toluidine blue test for the diagnosis of oral carcinoma; the histopathological examination was the gold standard.

\section{Main conclusions}

A prediction ranging from 76 to $85 \%$ was found in four pathological classes of the oral cavity, with a sensitivity of $98 \%$ and a specificity of $100 \%$ to differentiate abnormal from normal tissues. Thus, the study suggests the possibility of classifying pathological classes by the autofluorescence spectrum in vitro, making the method useful for places with low resources and limited clinical expertise.

The application of confocal reflectance allowed differentiating the lesions in the studied groups, suggesting its clinical usefulness in the evaluation of oral lesions, early diagnosis and malignant and premalignant oral lesions and real-time identification of tumor margins.

The difficulties, present in all cases, were the contact of the device with the anatomical surface, the sliding of the device, the fine tremors and the lack of sharpness of the image, which did not impair the performance and interpretation of the examination. The criteria were shown to be applicable to lesions of the mouth and lower lip.

There was a significant association between clinical examination using acetic acid and expression of p53 protein $(p=0.000)$. The findings suggest that $5 \%$ acetic acid has high sensitivity, specificity and accuracy in the detection of squamous cell carcinoma of the mouth, thus being useful for oral epidermoid cancer.

The most sensitive test was the toluidine blue test $(80.9 \%)$, that also had the highest negative predictive value (70.3\%), and the one with the highest specificity and the ability to detect malignant cells for evaluation was the cytologic scraping of lesions $(82.7 \%)$. Both test showed to be useful in the diagnosis of malignant lesions of the mouth, especially in places with a lower prevalence of the disease and in situations in which the biopsy is not a feasible procedure, thus preventing the definition of clinical screening.

The method has shown to be useful after its application in 15 patients with suspicious lesions, confirming that cytology has potential for screening malignant and premalignant lesions. 
Table 1 (conclusion)

\begin{tabular}{|c|c|c|c|c|c|}
\hline Título & $\begin{array}{l}\text { Período dos } \\
\text { dados }\end{array}$ & $\begin{array}{l}\text { Local de realização } \\
\text { do estudo }\end{array}$ & Intervention & Objective & Main conclusions \\
\hline \multicolumn{6}{|l|}{$\begin{array}{l}\text { REORGANIZATION OF THE } \\
\text { HEALTH SYSTEM }\end{array}$} \\
\hline $\begin{array}{l}\text { Prevention and detection } \\
\text { of oral cancer: participatory } \\
\text { planning as a strategy to } \\
\text { broaden coverage in the } \\
\text { elderly population [31]. }\end{array}$ & 2006-2011 & Brazil (São Paulo) & $\begin{array}{l}\text { Annual action for prevention } \\
\text { and early detection of oral } \\
\text { cancer, carried out with the } \\
\text { participative planning of the } \\
\text { health teams in a municipality } \\
\text { of São Paulo state. }\end{array}$ & $\begin{array}{l}\text { To evaluate the participatory } \\
\text { planning of the health } \\
\text { teams, seeking to identify } \\
\text { the difficulties encountered } \\
\text { and the strategies adopted } \\
\text { in the period of five years } \\
\text { (2006-2011) by analyzing the } \\
\text { coverage of oral exams for the } \\
\text { prevention and detection of } \\
\text { the disease. }\end{array}$ & $\begin{array}{l}\text { Strategies to cope with the } \\
\text { difficulties, coordination } \\
\text { issues and epidemiological } \\
\text { surveillance suggested by } \\
\text { dental surgeons led to an } \\
\text { increase in the coverage } \\
\text { of exams performed in the } \\
\text { population ( }>60 \text { years), which } \\
\text { increased from } 21 \% \text { in } 2006 \text { to } \\
62 \% \text { in } 2011 \text {. It was concluded } \\
\text { the development of strategies } \\
\text { with the participation of health } \\
\text { teams had satisfactory results. }\end{array}$ \\
\hline $\begin{array}{l}\text { Prevention and Early Detection } \\
\text { of Oral Cancer: Screening in } \\
\text { Risk Populations [32]. }\end{array}$ & $2000-2002$ & Brazil (São Paulo) & $\begin{array}{l}\text { Implementation of directed } \\
\text { examination of the mouth } \\
\text { and palpation of the cervical } \\
\text { ganglion chains followed by } \\
\text { referral of patients with lesions } \\
\text { for further investigations; } \\
\text { the target audience was } \\
\text { smokers and alcohol } \\
\text { consumers attended at the } \\
\text { studied health unit. }\end{array}$ & $\begin{array}{l}\text { To evaluate the feasibility of } \\
\text { a program for the prevention } \\
\text { and early diagnosis of oral } \\
\text { cancer directed at groups } \\
\text { considered at risk for this } \\
\text { disease. }\end{array}$ & $\begin{array}{l}\text { A high number of lesions were } \\
\text { diagnosed during the screening } \\
\text { of the at-risk population, } \\
\text { demonstrating the importance } \\
\text { of the periodic oral examination } \\
\text { in this group. However, the } \\
\text { proposed intervention, such as } \\
\text { the displacement of specific } \\
\text { teams for the screening of } \\
\text { patients, proved to be very } \\
\text { arduous and costly to be } \\
\text { effectively incorporated into } \\
\text { health care services. }\end{array}$ \\
\hline $\begin{array}{l}\text { Access to oral cancer } \\
\text { treatment in the regional } \\
\text { management collegiate } \\
\text { region [33]. }\end{array}$ & 2011 & Brazil (São Paulo) & $\begin{array}{l}\text { Monitoring of the outcome of } \\
\text { cases of patients attended } \\
\text { at DCs. }\end{array}$ & $\begin{array}{l}\text { To evaluate the outcome of } \\
\text { cases diagnosed as oral } \\
\text { cancer in reference services in } \\
\text { oncology. }\end{array}$ & $\begin{array}{l}\text { Biopsies are performed } \\
\text { with agility. There was no } \\
\text { counter-reference neither } \\
\text { monitoring of cases of oral } \\
\text { cancer. }\end{array}$ \\
\hline
\end{tabular}

Antunes et al. [10] stated the need for a back-up service to absorb people identified with suspicious lesions, as well as to monitor the results of the campaigns and patients referral.

For the development of these campaigns, the following strategies are necessary: training of professionals, elaboration of printed materials to guide municipal authorities on how to conduct such campaigns, training of the specialist responsible for the reassessment of the referred lesions, and expansion of services aimed at the diagnosis of lesions. The positive aspects of these campaigns were related to the qualification of the dental surgeons (DSs) involved, proximity to the residence of the target group and contact between the three levels of health care. Another relevant aspect was the relationship between the professional and the population, through a good communication and dissemination of information about protective and risk factors for oral health, maintaining a relationship of empathy with the other, valorization of community knowledge and use of an easy-tounderstand language.

\section{Non-invasive diagnostic methods}

Fifteen studies were classified in this topic addressing this topic [14-28]. From these, several studies [14, 15, 17, 19-23] have indicated the need to develop other methods for the diagnosis of oral lesions equivalent to biopsy, but with lower cost and easy-to-apply.
There were reports of use of methods to identify the presence of biomarkers suggestive of neoplastic alteration [24-28], videoroscopy [20], spectroscopy (fluorescence, diffuse reflectance) [18,21,29], and acetic acid application [16], endoscopy [17], modified exfoliative biopsy [23], toluidine blue test [15], and exfoliative cytology [15].

\section{Reorganization of the health system}

The studies classified in this category covered preventive activities associated with participatory planning and epidemiological surveillance [31], the implementation of physical examination of the mouth in a population at risk [32], organization of dental centers that are responsible for the diagnosis and referral of confirmed cases of cancer [33].

Bulgareli et al. [31] analyzed the effects of participatory planning. Among the actions implemented as a result of this strategy, they found the epidemiological surveillance performed by dental surgeons in the area of coverage of the primary health care unit as relevant and a guiding activity in decision making. This activity favored the increase of $21 \%$ to $62 \%$ of the coverage of examinations performed in the population over 60 years, with the consequent increase in the probability of identifying suspicious lesions.

The other study in this category [32], also carried out in the state of São Paulo, addressed the implementation 
of activities directed to "risk groups", including health education, occasional screening and referral of suspected lesions. The authors argue that in order to be less costly to the health service, these activities could be carried out periodically, combined with other health campaigns directed to this group.

Conducting explanatory/educational lectures also proved to be effective [31], specially when followed by orientation for self-examination and clinical examination by the oral health professional [32], with emphasis on dissemination tools to increase knowledge on the subject: distribution of leaflets; encouragement of regular visits to the dentist and self-care in oral health, including hygiene of teeth and prostheses; guidance on harmful habits, such as smoking and alcoholism; and self-examination.

Regarding the organization of Dental Centers (DC), the importance of monitoring suspected and confirmed cases was highlighted, indicating a better structuring of the reference and counter-referral system in order to speed up the process of early diagnosis and treatment in a timely manner. For this purpose, a system that encompasses the entire work process is needed [10].

\section{DISCUSSION}

The practice of prevention and early diagnosis of diseases is advocated worldwide, as it enables a curative intervention for most types of cancers in a timely manner. Thus, we sought to identify such practices in primary and secondary care for the control, prevention and early diagnosis of oral cancer, verifying which actions have been successful in Brazil and in the world in order to help increasing the rates of cure of this disease.

The current hegemonic concept of Primary Health Care (PHC) includes actions to promote health and prevent disease, in addition to care (32). PHC has in Brazil, especially through the family health strategy (FHS), absolute centrality in the organization of the health system [34]. Oral health has been inserted into the basic team since 2000, and since then $\mathrm{OH}$ Brazilian policies have clearly established the role of the secondary level with the Dental Centers (DCs) [11].

Efforts have been identified at the PHC level to develop awareness and information about the problem, risk factors and signs and symptoms of oral cancer. The identification of risk groups among the population assigned to health units is important, since the intervention in this population has a differential effect, considering its greater risk of becoming ill and possibly a greater chance of developing pre-malignant and malignant lesions $[10,12,13]$. Such activities seek to promote change in the habits and attitudes of the population towards a healthy lifestyle. These actions must be carried out by primary health care professionals, whether they work on oral health or not, in partnership with the other levels of health care, thus strengthening the integration between them $[12,13]$.

Oral cancer has also affected people who do not have the traditional risk factors and at younger age.
Thus, despite the need for differentiated attention to risk groups [36], educational activities should not be restricted to them alone. However, current evidence on the benefits and risks of screening for oral cancer in asymptomatic adults is insufficient to support screening for population screening without discriminating "risk group" [14].

At the secondary health care level, it is necessary to introduce new methods of diagnosis of oral cavity lesions that are more cost-effective, easier to handle and fast to achieve results in order to facilitate the early identification of the problem. The achievement of population tracking combined with awareness campaigns are actions that enhance one another [15].

Early diagnosis of oral cancer is a differential factor for the outcome of cases, and detection in the pre-malignant phase can improve the incidence and mortality rates of this disease [38]. Thus, the use of high-sensitivity and -specificity screening methods is essential to change the panorama of high rates of late diagnosis. Screening targets people who are or think themselves healthy, and noninvasive methods improve test acceptance. Because they are easier to handle and quick to analyze, suspicious lesions may be better defined and have an abbreviated outcome, with positive repercussions in the conduction of cases. In addition, the need for a surgical biopsy may contribute to the delay in diagnosis due to the time to schedule it and to obtain the result, especially in poorer areas and with less diagnostic resources. However, it is important to emphasize that biopsy is still mandatory in highly suspected lesions and intended specifically for these lesions, due to its potential for morbidity $[16,17]$.

All these methods have advantages and disadvantages, and can be used in secondary care to facilitate diagnosis. Currently, there are no national programs based on oral cancer screening on implementation, but timely screening has been advocated [40]. These non-invasive alternatives are poorly disseminated in health services and the gold standard for tracking oral cancer continues to be visual inspection under white light and palpation by a physician or dentist. This procedure, however, is limited for being dependent on the examiner's experience, and this limitation supports the development of more objective diagnostic techniques. In spite of the scarcity of studies that justify the use of these non-invasive methods mentioned above as front line in the tracking, they are very useful in situations in which the biopsy is not available $[38,40]$. The objective was to replace non-invasive techniques in places where biopsy cannot be performed in a timely manner, or even to facilitate the tracking of lesions in apparently healthy people with or without risk factors for cancer, since for screening it is recommended to use of a method that is not invasive and that makes it possible to differentiate malignant and benign lesions.

Even with several possibilities for diagnostic methods, rates still indicate that patients are diagnosed in advanced stages of cancer (38-40).

This finding points to the urgent need for reorganization of public care in dentistry, both at the primary and secondary 
levels, aiming at the flow of patients in the care network, which is crucial for the impact on morbidity and mortality indicators. Without the effective reorganization of the health care system and care network for these patients, despite the advances in the oncology area regarding methods of diagnosis and treatment, oral cancer will continue to be a public health problem.

Among the recommendations for the organization of the Brazilian health system, it is emphasized the importance of the municipalization of services [7], with the actions implanted and evaluated within the regions and effective reference and counter-reference in stomatology to the area of coverage as an essential factor to an organized flow within the network. Other actions were also relevant to improve oral health performance, such as the training strategies of the professionals involved [32], the development of materials to guide municipalities in the conduction of campaigns [31], effective establishment of reference flows [7,32], practical training with the dentist in the unit [31], re-examination in individuals with soft tissue alterations [32] and more services for the diagnosis of oral lesions[31,32]. The participatory planning [31] had its proven success, being able to be used as model for other units, respecting the peculiarity of each locality and organization of the reference flow system and counter-reference. The absence of a support service for people addressed in these campaigns will result in the failure to provide care to patients with potentially malignant lesions in order to solve the identified problem. Important inequalities were identified in the use of oral health services in the FHT [44], as well as the marked effect of social determinants of health on outcomes in oral health [45], aspects not valued in the studies analyzes in this review.

Some limitations of this review should be highlighted. The choice of the period was due to the publication of the Brazilian oral health policy, in order to identify experiences in Brazil and in the world from this period. However, in view of the time frame between the events portrayed and the publication in an article format, experiences prior to this period were captured. Some choices, such as limited languages and retrieving only articles available in free access databases or in the CAPES journal base may have limited the scope of articles achieved, but were important for the feasibility of the work. The great majority of the studies found favorable results in the analyzed interventions, and many of them were carried out by the actors involved. Such a finding may be due to the tendency not to publish negative findings. Finally, no filter was applied regarding the quality of the studies.

\section{CONCLUSIONS}

The challenge for the early diagnosis of oral cancer is not only a national one but a worldwide problem, and it is related to a number of factors, such as: the profile of people affected, difficulty in accessing a dentist, invasive methods of early diagnosis, lack of dissemination of information for the population, knowledge limitations of professionals working in the area and a deficit of approaching this content in the university curriculum.

The studies included in this article have different focuses on the prevention and early diagnosis of oral cancer. They address the knowledge on the profile of the most vulnerable groups and the necessary information about the problem, such as awareness campaigns; the available and the alternative approaches to patient care, such as population screening, implementation of new strategies for the early detection of this pathology by different diagnostic methods; the role of professionals, the appreciation of the dental surgeon and the necessary permanent education of oral health professionals, and the reorganization of the health system and services, with the involvement of all health teams and integration of health care levels.

This review included 22 articles published over a period of 13 years. We found reports of interventions in the categories of non-invasive diagnostic methods, awareness and tracking campaigns, and reorganization of the health system.

Despite the possibility of publication bias, most of the reviews showed positive results in increasing the early detection of cases. An exception was the active search for suspected cases in the population, since the cost-benefit did not compensate the expenditure with human resources for this purpose. Another important point is that the use of noninvasive methods for diagnosis of lesions has been found useful only as auxiliary methods in cases in which the biopsy is not available or when its result may delay the diagnosis because it remains as the standard gold in the diagnosis of malignant lesions.

\section{REFERENCES}

1. World Health Organization. The world oral health report 2003. Continuous improvement of oral health in the 21 st century-the approch of the WHO Global Oral Health Programme. 2003

2. Narval PC, Frazão P. Saúde bucal no Brasil muito além do céu da boca FIOCRUZ; 2008. https://doi.org/10.7476/9788575413630

3. Brentani MM, Coelho FRG, Kowalski LP. Bases da oncologia. São Paulo: Lemar; 2003.

4. Oliveira MM de, Malta DC, Guauche H, Moura L de, Silva GA e. Estimativa de pessoas com diagnóstico de câncer no Brasil: dados da Pesquisa Nacional de Saúde, 2013. REV BRAS EPIDEMIOL. 2015;146-57. https:// doi.org/10.1590/1980-5497201500060013

5. Brasil Ministério da Saúde. Estimativas 2016: Incidência de Câncer no Brasil. Instituto Nacional de Câncer; 2015

6. Ministério da Saúde. Diretrizes da Política Nacional de Saúde Bucal. 2004

7. Torres-Pereira CC, Angelim-Dias A, Melo NS, Jr. CAL, Oliveira EMF de. Abordagem do câncer de boca: uma estratégia para os níveis primário e secundário de atenção em saúde. Cad Saúde Pública. 2012;28:Sup:S30-S39

8. Souza MT de, Silva MD da, Carvalho R de. Revisão integrativa: o que é e como fazer. einstein. 2010;102-6.

9. Brasil. Ministério da Saúde. Diretrizes da Política Nacional de Saúde Bucal. 2004

10. Antunes JLF, Toporcov TN, Wunsch-Filho V. Resolutividade da campanha de prevenção e diagnóstico precoce do câncer bucal em São Paulo, Brasil. Rev Panam Salud Publica. 2007 01PY - 2007;21(1):30-6.

11. Cruz GD, Ostroff JS, Kumar JV, Gajendra S. Preventing and detecting oral cancer. Oral health care providers' readiness to provide health behavior counseling and oral cancer examinations. J Am Dent Assoc 1939. 2005 May;136(5):594-601; quiz 681-682.

12. Maia A de MO, Cruz CM de SB, Leão JC, Cavalcanti UDNT. Diagnóstico precoce de lesões orais potencialmente malignas em dois municípios do Estado de Pernambuco. Odontol Clínico-Científica Online. 2013 Mar;12(1):47-51 
13. Martins JS, Abreu SCC de, Araújo ME de, Bourget MMM, Campos FL de, Grigoletto MVD, et al. Estratégias e resultados da prevenção do câncer bucal em idosos de São Paulo, Brasil, 2001 a 2009. Rev Panam Salud Publica. 2012 03PY - 2012;31(3):246-52.

14. Burzalaff JB. Estudos sobre a aplicabilidade da citopatologia no diagnóstico precoce do câncer bucal [Tese de Doutorado]. [Porto Alegre]: Universidade Fedderal do Rio Grande do Sul (UFRGS); 2007.

15. Ramos GHA, Oliveira BV de, Biasi LJ, Sampaio Júnior LA. Avaliação da citologia e do teste do azul de toluidina no diagnóstico dos tumores malignos da mucosa oral. Rev Bras Cir Cabeça Pescoço. 2007;36(1):27-9.

16. Bhalang K, Suesuwan A, Dhanuthai K, Sannikorn P, Luangjarmekorn $\mathrm{L}$, Swasdison S. The application of acetic acid in the detection of oral squamous cell carcinoma. Oral Surg Oral Med Oral Pathol Oral Radiol Endodontology. 2008 Sept;106(3):371-6. https://doi.org/10.1016/j. tripleo.2008.01.017

17. Ramos GHA, Tavares MR, Dedivitis RA, França CM, Oliveira BV, Pedruzzi PA. Endoscopia de contato (microestomatoscopia) nas lesões da boca e do lábio: avaliação do método. Rev Col Bras Cir. 2008;35(6):355-60. https://doi.org/10.1590/S0100-69912008000600003

18. Anuthama K, Sherlin HJ, Anuja N, Ramani P, Premkumar P, Chandrasekar T. Characterization of different tissue changes in normal, betel chewers, potentially malignant lesions, conditions and oral squamous cell carcinoma using reflectance confocal microscopy: Correlation with routine histopathology. Oral Oncol. 2010 Apr;46(4):232-48. https://doi. org/10.1016/j.oraloncology.2009.12.008

19. Chaturvedi P, Majumder S, Krishna H, Muttagi S, Gupta P. Fluorescence spectroscopy for noninvasive early diagnosis of oral mucosal malignant and potentially malignant lesions. J Cancer Res Ther. 2010;6(4):497. https://doi.org/10.4103/0973-1482.77097

20. Conde DC, Calandro TLL, Campos IT, Dias EP. A vídeo-câmera intraoral como instrumento auxiliar no exame dos pacientes com risco aumentado para câncer bucal [The intraoral video camera: a diagnostic tool in the exam of patient with increased oral cancer risk]. Rev Clín Pesq Odontol Impr. 2010 04PY - 2010;6(1):49-55.

21. Stephen MM, Jayanthi JL, Unni NG, Kolady PE, Beena VT, Jeemon P, et al. Diagnostic accuracy of diffuse reflectance imaging for early detection of pre-malignant and malignant changes in the oral cavity: a feasibility study. BMC Cancer. 2013;13(1):1. https://doi.org/10.1186/1471-2407-13-278

22. Fontes KBF da C, Cunha KSG, Rodrigues FR, Silva LE da, Dias EP. Concordance between cytopathology and incisional biopsy in the diagnosis of oral squamous cell carcinoma. Braz Oral Res. 2013 03PY 2013;27(2):122-7.

23. Gupta S, Shah J, Parikh S, Limbdiwala P, Goel S. Clinical correlative study on early detection of oral cancer and precancerous lesions by modified oral brush biopsy and cytology followed by histopathology. J Cancer Res Ther. 2014;10(2):232. https://doi.org/10.4103/0973-1482.136539

24. Tang X-H, Urvalek AM, Osei-Sarfo K, Zhang T, Scognamiglio T, Gudas LJ. Gene expression profiling signatures for the diagnosis and prevention of oral cavity carcinogenesis-genome-wide analysis using RNAseq technology. Oncotarget. 2015 Sept;6(27):24424-35. https://doi. org/10.18632/oncotarget.4420

25. Yong-Deok K, Eun-Hyoung J, Yeon-Sun K, Kang-Mi P, Jin-Yong L, SungHwan C, et al. Molecular genetic study of novel biomarkers for early diagnosis of oral squamous cell carcinoma. Med Oral Patol Oral Cir Bucal. 2015 Mar;20(2):e167-79. https://doi.org/10.4317/medoral.20229

26. Jiang W-P, Wang Z, Xu L-X, Peng X, Chen F. Diagnostic model of saliva peptide finger print analysis of oral squamous cell carcinoma patients using weak cation exchange magnetic beads. 2015 July;35(3). Available from: http://www.ncbi.nlm.nih.gov/pmc/articles/PMC4613719/?tool=pubmed

27. Mankapure PK, Barpande SR, Bhavthankar JD, Mandale M. Serum big endothelin-1 as a biomarker in oral squamous cell carcinoma patients: an analytical study. J Appl Oral Sci. 2015 Nov;23(5):491-6. https://doi. org/10.1590/1678-775720150125

28. Zhang $Y$, Chen $R, X u$ L, Ning $Y$, Xie S, Zhang G-J. Silicon nanowire biosensor for highly sensitive and multiplexed detection of oral squamous cell carcinoma biomarkers in saliva. Anal Sci. 2015 Mar;31(2):73-8. https:// doi.org/10.2116/analsci.31.73
29. Chaturvedi P, Majumder SK, Krishna H, Muttagi S, Gupta PK. Fluorescence spectroscopy for noninvasive early diagnosis of oral mucosal malignant and potentially malignant lesions. J Cancer Res Ther. 2010 00PY 2010;6(4):497-502.

30. Liu Y, Li J, Liu X, Liu X, Khawar W, Zhang X, et al. Quantitative risk stratification of oral leukoplakia with exfoliative cytology. PLoS One. 2015 May;10(5):e0126760-e0126760. https://doi.org/10.1371/journal. pone. 0126760

31. Bulgareli JV, Diniz OCCF, Faria ET de, Vazquez F de L, Cortellazzi KL, Pereira AC. Prevenção e detecção do câncer bucal: planejamento participativo como estratégia para ampliação da cobertura populacional em idosos. Ciênc Saúde Coletiva. 2013 12PY - 2013;18(12): 3461-73.

32. Scheufen R de C, Almeida FCS, Silva DP da, Araujo ME de, Palmiere M Pegoretti $\mathrm{T}$, et al. Prevenção e Detecção Precoce do Câncer de Boca: Screening em Populações de Risco. Pesqui Bras Odontopediatria Clín Integr [Internet]. 2012 02PY - 2012;11(02). Available from: http://revista. uepb.edu.br/index.php/pboci/article/viewFile/1442/683

33. Sampaio ET de M, Oliveira AMG, Pereira AC, Meneghim M de C. Acesso ao tratamento do câncer bucal na região do colegiado de gestão regional de Campinas-SP: estudo de caso. Rev Odontol Univ Cid São Paulo Online [Internet]. 2015 Aug;27(2). Available from: http://arquivos. cruzeirodosuleducacional.edu.br/principal/old/revista odontologia/pdf/ maio_agosto_2015/Odonto_02_2015_150-155.pdf

34. Borges CF, Baptista TWF. A política de atenção básica do ministério da saúde: refletindo sobre a definição de prioridades. Trab Educ Saúde. 2010;8(1):27-53. https://doi.org/10.1590/S1981-77462010000100003

35. Mattos GCM, Ferreira EF e, Leite ICG, Greco RM, Universidade Federal de Minas Gerais, Brasil, Universidade Federal de Juiz de Fora. A inclusão da equipe de saúde bucal na Estratégia Saúde da Família: entraves, avanços e desafios. Ciênc Saúde Coletiva. 2014 Feb;19(2):373-82. https://doi org/10.1590/1413-81232014192.21652012

36. Steele TO, Meyers A. Early detection of premalignant lesions and ora cancer. Otolaryngol Clin North Am. 2011 OOPY - 2011;44(1):221-9, vii.

37. Mitka M. Evidence lacking for benefit from oral cancer screening. JAMA. 2013 05PY - 2013;309(18):1884-1884

38. Sweeny L, Dean NR, Magnuson JS, Carroll WR, Clemons L, Rosenthal EL. Assessment of tissue autofluorescence and reflectance for ora cavity cancer screening. Otolaryngol Head Neck Surg. 2011 12PY 2011;145(6):956-60.

39. Mehrotra R, Gupta DK. Exciting new advances in oral cancer diagnosis: avenues to early detection. Head Neck Oncol. 2011;3(1):1. https://doi. org/10.1186/1758-3284-3-33

40. Walsh T, Liu JL, Brocklehurst P, Glenny AM, Lingen M, Kerr AR, et al. Clinical assessment to screen for the detection of oral cavity cancer and potentially malignant disorders in apparently healthy adults. Cochrane Database Syst Rev. 2013 12PY - 2013;11:CD010173-CD010173.

41. Fedele S. Diagnostic aids in the screening of oral cancer. Head Neck Oncol. 2009 03PY - 2009;1:5-5

42. López BAM, Chamorro CPM. Nanochips y nanosensores para el diagnóstico temprano de cáncer oral: una revisión. 2012.

43. Carrera Torres A, Cobos Fuentes M-J, Gallardo Castillo I, Caballero Aguilar J, Martínez-Sahuquillo Márquez A. Quimioluminiscencia como método de screening de cáncer oral. Av En Odontoestomatol. 2011:27(6):301-11. https://doi.org/10.4321/S0213-12852011000600004

44. Soares FF, Chaves SCL, Cangussu MCT. Desigualdade na utilização de serviços de saúde bucal na atenção básica e fatores associados em dois municípios brasileiros. 2013 [cited 2017 May 9]; Available from: http://iris. paho.org/xmlui/handle/123456789/8721

45. Bueno RE, Moysés ST, Bueno PAR, Moysés SJ. Determinantes sociais e saúde bucal de adultos nas capitais do Brasil. 2014 [cited 2017 May 9]; Available from: http://iris.paho.org/xmlui/handle/123456789/ 7844

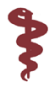

